Bangladesh J. Plant Taxon. 20(2): 233-238, 2013 (December)

(C) 2013 Bangladesh Association of Plant Taxonomists

\title{
STATUS OF RESEDA PENTAGYNA ABDALLAH \& A.G. MILLER (RESEDACEAE) INFERRED FROM COMBINED NUCLEAR RIBOSOMAL AND CHLOROPLAST SEQUENCE DATA
}

\author{
M. Ajmal Ali ${ }^{1}$, Fahad M. Al-Hemaid, Ritesh K. Choudhary ${ }^{2}$, \\ JoOngKu LeE ${ }^{2}$, SoO-Yong KIM ${ }^{2}$ AND M.A. RuB ${ }^{3}$ \\ Department of Botany and Microbiology, College of Science, \\ King Saud University, Riyadh 11451, Saudi Arabia
}

Keywords: Reseda pentagyna; Resedaceae; Saudi Arabia; Endemic; ITS; trnL-F.

\begin{abstract}
The present study focuses on the status of Reseda pentagyna Abdallah \& A.G. Miller (Resedaceae). The internal transcribed spacer (ITS) region of nuclear ribosomal DNA and chloroplast trnL-F gene of the questioned species were sequenced. The Basic Local Alignment Search Tool (BLAST) search showed maximum identity with $R$. stenostachya. The parsimony analysis of ITS, trnL-F and combined sequences data analyses revealed grouping of Reseda species consistent with established taxonomic sections of the genus, $R$. pentagyna showed proximity with $R$. stenostachya $(100 \%$ bootstrap support), nested within the clade of section Reseda.
\end{abstract}

\section{Introduction}

The Resedaceae include six genera (i.e. Caylusea A. St.-Hil, Ochradenus Delile, Oligomeris Cambess., Randonia Coss., Reseda L. and Sesamoides Ortega) with approximately 85 species, and are widely distributed in the Old World, with a major center of species diversity in the Mediterranean basin (Martín-Bravo et al., 2007). The members of the family Resedaceae has been traditionally considered closely related to Capparaceae and Brassicaceae; however, the Angiosperm Phylogeny Group placed it under the order Brassicales (APG III, 2009).

The genus Reseda consists of approximately 65 species, mostly restricted to the Mediterranean basin, while four of them (i.e. Reseda alba L., R. lutea L., R. luteola L. and $R$. phyteuma L.) are distributed throughout the world (Martín-Bravo et al., 2007). The genus Reseda in Saudi Arabia is represented by seven species, viz. R. alba, R. arabica Boiss., R. aucheri Boiss., $R$. lutea, R. muricata C. Presl, R. pentagyna Abdallah \& A.G. Miller and $R$. sphenocleoides Deflers (Chaudhary, 1999). Among these, $R$. pentagyna is endemic to Saudi Arabia, and reported to occur in Northern Hijaz mountain area, Wadi Sawawin and Tabuk of north western Saudi Arabia (Miller and Nyberg, 1994; Chaudhary, 1999; Llewellyn et al., 2010). R. stenostachya is the most closely allied taxon to the endemic $R$. pentagyna which differs from the latter by presence of only 3-4 toothed capsules as compared to the 5-6 toothed capsules in the latter.

In the last two decades, the internal transcribed spacer sequences of nuclear ribosomal DNA has gained much attention, not only because of its efficacy in carrying out phylogeny of the plants at lower taxonomic level, but also to be considered as the most trusted markers available for the DNA barcoding of the plants. Even after facing criticism of its utility, this marker stands parallel

${ }^{1}$ Corresponding author. Email: majmalali@rediffmail.com

${ }^{2}$ International Biological Material Research Center, Korea Research Institute of Bioscience and Biotechnology, Daejeon-305 806, South Korea.

${ }^{3}$ National Herbarium \& Genebank, National Agriculture \& Animal Resources Research Center, Riyadh-11484, Saudi Arabia. 
to the smartest genes available for the molecular phylogeny and plant DNA barcoding. Since the intrigued morphological similarities observed in between $R$. pentagyna and $R$. stenostachya (Miller and Nyberg, 1994; Chaudhary, 1999) we planned to carry out molecular phylogenetic analysis of internal transcribed spacer sequences (ITS) of nuclear ribosomal DNA and trnL-F sequences to confirm the species status of $R$. pentagyna.

\section{Materials and Methods}

The leaf material of $R$. pentagyna was collected from Wadi Sirr area of Saudi Arabia, and the taxonomic identification was confirmed through consultation of Flora of Saudi Arabia (Chaudhary, 1999) and protologue (Miller and Nyberg, 1994). Total genomic DNA was extracted using the DNeasy Plant Mini kit (QIAGEN, Valencia, CA, USA). The nuclear (internal transcribed spacer sequences of nuclear ribosomal DNA), and plastid (trnL-F) genes were amplified using AccuPower HF PCR PreMix (Bioneer, Daejeon, South Korea). The standard primers ITS (White et al., 1990) and trnL-trnL-F (Taberlet et al., 1991) were used for amplification and cycle sequencing. The amplified products were purified using PCR purification kit (SolGent, Daejeon, South Korea) prior to sequencing. The purified amplified products were sequenced using ABI PRISM 3730XL (Perkin-Elmer/Applied Biosystem, USA) following manufacturer's protocol. Each sample was sequenced in the sense and anti-sense direction. The nucleotide sequences of both the DNA strands (sense and anti-sense) were obtained and analyzed using Sequence Navigator (Perkin-Elmer/Applied Biosystems) to ensure accuracy of the base pair sequence.

For the molecular phylogenetic analysis, ITS and trnL-F sequences of a total of 36 related species of Reseda (comprising representative from all six sections i.e. Glaucoreseda, Leucoreseda, Luteola, Neoreseda, Phyteuma and Reseda as recognized by Martín-Bravo et al., 2007) were retrieved from GenBank (Table 1). According to Martín-Bravo et al. (2007) Oligomeris arose within the ranks of Reseda; hence, sequences of Oligomeris were retrieved from GenBank, and were used as outgroup in the phylogenetic analyses (Table 1). Sequence alignments were performed using Clustal X, version 1.81 (Thompson et al., 1997). Sequence alignments were subsequently adjusted manually using BioEdit (Hall, 1999). Gaps were treated as missing data in phylogenetic analyses. The voucher specimen (Chaudhary et al. 13704) of sequenced plant accession deposited at National Herbarium (RIY) of Saudi Arabia; and the generated sequences submitted in GenBank (Table 1). Maximum parsimony (MP) analysis was performed using PAUP* 4.0b10 (Swofford, 2002).

\section{Results and Discussion}

The combined length of ITS region (ITS1-5.8S-ITS2) in Reseda pentagyna was 634 bp. The ITS1 region was 261 bp (GC content 61\%), the 5.8S gene was 162 bp (GC content 56\%), and the ITS2 region was 211 bp (GC content 63\%). The trnL-F sequence in $R$. pentagyna was $777 \mathrm{bp}$ (GC content 33\%). BLAST search of ITS sequence of $R$. pentagyna showed maximum identity (99\%) with $R$. stenostachya followed by $R$. aucheri and $R$. ellenbeckii (95\%), while trnL-F sequence showed maximum identity (100\%) with $R$. stenostachya followed by $R$. alphonsi, $R$. buhseana, $R$. gilgiana and $R$. sessilifolia (97\%). ITS sequence of $R$. pentagyna differs from $R$. stenostachya at position 67 and 75 in alignment, however, in trnL-F sequences, no base pair difference was observed in between sequence of $R$. pentagyna and $R$. stenostachya. Sequence characteristics and statistics of maximum parsimony trees derived from analyses of ITS, trnL-F and combined data are summarized in Table 2. The maximum parsimony tree derived from analysis of ITS and trnL-F sequence revealed comparatively week bootstrap support than combined analysis; and therefore, only the maximum parsimony trees topology derived from analysis of combined sequence data is discussed here. 
Table 1. Plant accessions used for the molecular phylogenetic analysis of Reseda pentagyna.

\begin{tabular}{|c|c|c|}
\hline \multirow[t]{2}{*}{ Taxa } & \multicolumn{2}{|c|}{ GenBank Accession No. } \\
\hline & ITS & $\operatorname{trnL}-\mathrm{F}$ \\
\hline \multicolumn{3}{|l|}{ Ingroup } \\
\hline \multicolumn{3}{|l|}{ Sect. Glaucoreseda } \\
\hline 1. Reseda battandieri Pit. & DQ987183 & DQ987045 \\
\hline 2. R. complicata Bory & DQ987172 & DQ987046 \\
\hline 3. R. glauca L. & DQ987182 & DQ987040 \\
\hline 4. R. gredensis (Cutanda \& Willk.) Müll.-Arg. & DQ987174 & DQ987047 \\
\hline 5. R. virgata Boiss. \& Reut. & DQ987177 & DQ987048 \\
\hline \multicolumn{3}{|l|}{ Sect. Luteola } \\
\hline 6. R. luteola L. & DQ987187 & DQ987050 \\
\hline \multicolumn{3}{|l|}{ Sect. Leucoreseda Subsect. Leucoreseda } \\
\hline 7. R. alba L. & DQ987198 & DQ987053 \\
\hline 8. R. attenuata Ball & DQ987201 & DQ987057 \\
\hline 9. $R$. gayana Boiss. & DQ987205 & DQ987055 \\
\hline 10. R. undata L. & DQ987203 & DQ987056 \\
\hline 11. R.valentina Pau & DQ987207 & DQ987059 \\
\hline \multicolumn{3}{|l|}{ Sect. Leucoreseda Subsect. Erythroreseda } \\
\hline 12. R. suffruticosa Loefl. & DQ987210 & DQ987062 \\
\hline \multicolumn{3}{|l|}{ Sect. Neoreseda } \\
\hline 13. R. ellenbeckii Perkins & DQ987110 & DQ986998 \\
\hline 14. R. telephiifolia (Chiov.) Abdallah \& de Wit & DQ987128 & DQ986994 \\
\hline \multicolumn{3}{|l|}{ Sect. Phyteuma } \\
\hline 15. $R$. alopecuros Boiss. & DQ987139 & DQ987028 \\
\hline 16. R. arabica Boiss. & DQ987132 & DQ987029 \\
\hline 17. $R$. collina Müll.-Arg. & DQ987136 & DQ987031 \\
\hline 18. R. diffusa Ball & DQ987141 & DQ987033 \\
\hline 19. R. inodora Rchb. & DQ987142 & DQ987030 \\
\hline 20. $R$. odorata L. & DQ987133 & DQ987026 \\
\hline 21. $R$. orientalis (Müll.-Arg.) Boiss. & DQ987137 & DQ987025 \\
\hline 22. R. phyteuma L. & DQ987146 & DQ987032 \\
\hline \multicolumn{3}{|l|}{ Sect. Reseda } \\
\hline 23. R. alphonsi Müll.-Arg. & DQ987108 & DQ987005 \\
\hline 24. R. amblycarpa Fresen. & DQ987125 & DQ987001 \\
\hline 25. R. aucheri Boiss. & DQ987123 & DQ986989 \\
\hline 26. R. buhseana Müll.-Arg. & DQ987119 & DQ987004 \\
\hline 27. $R$. crystallina Webb \& Berthel. & DQ987088 & DQ987021 \\
\hline 28. $R$. gilgiana Perkins & DQ987114 & DQ986999 \\
\hline 29. R. lanceolata Lag. & DQ987099 & DQ987015 \\
\hline 30. R. lutea L. & DQ987094 & DQ987018 \\
\hline 31. R. pentagyna Abdallah \& Miller & JX867260 & JX867261 \\
\hline 32. $R$. sessilifolia Thulin & DQ987127 & DQ986995 \\
\hline 33. R. sphenocleoides Deflers & DQ987117 & DQ986993 \\
\hline 34. R. stenostachya Boiss. & DQ987156 & DQ987007 \\
\hline 35. R. stricta Pers. & DQ987103 & DQ987013 \\
\hline 36. $R$. urnigera Webb & DQ987098 & DQ987014 \\
\hline 37. $R$. viridis Balf. f. & DQ987130 & DQ986996 \\
\hline \multicolumn{3}{|l|}{ Outgroup } \\
\hline 38. Oligomeris dipetala (Aiton) Turcz. & DQ987168 & DQ987037 \\
\hline 39. O. dregeana (Müll. Arg.) Müll.-Arg. & DQ987166 & DQ987038 \\
\hline 40. O. linifolia (Vahl) J.F. Macbr. & DQ987165 & DQ987039 \\
\hline
\end{tabular}


Table 2. Summary of sequence characteristics and MP trees derived from analyses of ITS, trnL-F and combined data.

\begin{tabular}{lccc}
\hline Characters & ITS & trnL-F & Combined data \\
\hline Number of taxa included in analysis (including outgroup) & 40 & 40 & 40 \\
Sequence characteristics & & & \\
$\quad$ Length of sequenced & $627-639$ & $698-785$ & $1325-1424$ \\
Aligned length & 644 & 955 & 1622 \\
$\quad$ Parsimony informative & 92 & 146 & 433 \\
Tree characteristics & & & \\
Number of trees & 334 & 323 & 1299 \\
Length & 339 & 327 & 1305 \\
CI (Consistency Index) & 0.643 & 0.832 & 0.656 \\
RI (Retention Index) & 0.885 & 0.926 & 0.860 \\
RC (Rescaled Consistency Index) & 0.569 & 0.770 & 0.564 \\
HI (Homoplasy Index) & 0.478 & 0.318 & 0.446 \\
\hline
\end{tabular}

The bootstrap strict consensus tree resulted from combined sequence data analysis has been shown in Fig. 1. The study revealed the grouping of Reseda species according to previously recognized taxonomic sections, which is consistent with earlier report (Martín-Bravo et al., 2007). Moreover, $R$. pentagyna nested within the clade of the section Reseda, and showed proximity (100\% bootstrap support) with morphologically similar $R$. stenostachya. The ITS sequence of $R$. pentagyna (which was described based on 5-6 toothed capsule characters) differs from morphologically allied $R$. stenostachya (3-4 toothed capsule) at aligned position 67 (C in $R$. pentagyna but missing nucleotide in $R$. stenostachya) and 75 (C in $R$. pentagyna, T in $R$. stenostachya) possibly due to nucleotide polymorphism, a known features of ITS sequences of nrDNA.

Bentham and Hooker (1862) reported Reseda as a polymorphic genus with not more than 30 existing species. Latter, Abdallah and de Wit (1978) updated the list with some addition, and emphasized the need of experimental taxonomical research to get a strong support for the delimitation of species. Muller (1864) also described the variations in the morphology of leaf blades of Reseda that might be arranged in various manners and could be entire, crenate to ternately or pinnately (or rarely bi-pinnately) lobed. The occurrence of brachycarpous or macrocarpous capsules in Reseda is a known feature (Muller, 1864). Under various ecological conditions, plants may show certain morphological changes, viz. R. lutea shows change in the proximity of the veins in the lamina (Abdallah and de Wit, 1978). Further, the emergence of indumentums depends more or less on the moisture content present in the plant. In dry condition, these hairs can shrink, flatten or curl; while in wet conditions, they appear as blisters, or a scabrid, or muricated surface. As variations in fruit size within the same species usually do occur, therefore it cannot be taken as a strong taxonomic character for species level delimitation (Donald, 1988); and thus, the wide degree of variation in quantitative fruit-spine characters limits their use taxonomically. The proximity of questioned sequenced material with $R$. stenostachya in the MPTs indicates the quantitative differences of tooth characters or the variable trait which limits its use in species delimitation; therefore, we herein propose the merger of $R$. pentagyna into $R$. stenostachya. 


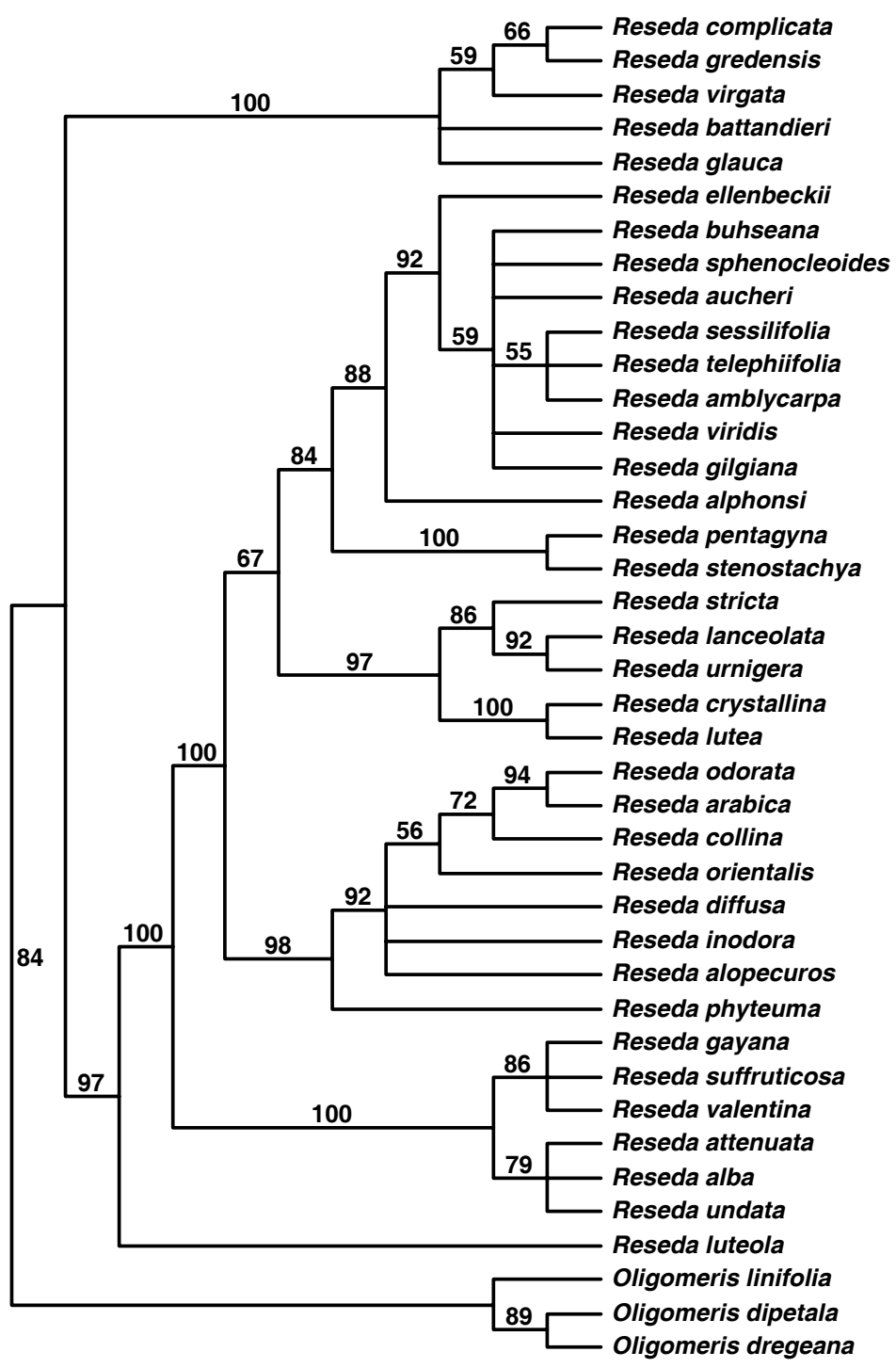

Fig. 1. Bootstrap strict consensus tree inferred from combined sequence data analysis of internal transcribed spacer (ITS) sequence of nuclear ribosomal DNA and trnL-F region. The Bootstrap strict consensus tree of 1299 maximally parsimonious trees (MPTs) with a total length of 1305 steps, a consistency index (CI) of 0.656, a homoplasy index (HI) of 0.446, rescaled consistency index (RC) of 0.564 and a retention index (RI) of 0.860 . Bootstrap values greater than $50 \%$ in 1000 bootstrap replicates are shown above lines.

\section{Acknowledgement}

The authors would like to extend their sincere appreciation to the Deanship of Scientific Research at King Saud University for its funding of this research through the Research Group Project No. RGP-VPP-195. 


\section{References}

Abdallah, M.S. and de Wit, H.C.D. 1978. The Resedaceae: a taxonomical revision of the family. Meded. Landbouwhoogeschool, Wageningen, p. 78.

APG III 2009. An update of the angiosperm phylogeny group classification for the orders and families of flowering plants. Bot. J. Linn. Soc. 161: 105-121.

Bentham, G., and Hooker, J.D. 1862. Genera Plantarum. Reeve, Williams \& Norgate, London.

Chaudhary, S. 1999. Resedaceae. In: Chaudhary, S. (Ed.), Flora of the Kingdom of Saudi Arabia. Ministry of Agriculture and Water, National Herbarium, National Agriculture and Water Research Center, Riyadh, Saudi Arabia, pp. 536-543.

Donald, H.L. 1988. The evolution of achene morphology in Ceratophyllum (Ceratophyllaceae), II. Fruit variation and systematic of the "spiny-margined” group. Syst. Bot. 13(1): 73-86.

Felsenstein, J. 1985. Confidence limits on phylogenies: an approach using the bootstrap. Evolution. 39: 783791.

Hall, T.A. 1999. BioEdit: A user-friendly biological sequence alignment editor and analysis program for Windows 95/98/NT. Nuc. Acids Symp. Ser. 41: 95-98.

Llewellyn, O.A., Hall, M., Miller, A.G., Al-Abbasi, T.M., Al-Wetaid, A.H., Al-Harbi, R.J., Al-Shammari, K.F. and Al-Farhan, A. 2010. Important plant areas in the Arabian Peninsula: 1. Jabal Qaraqir. Edinb. J. Bot. 67: 37-56.

Martín-Bravo, S., Meimberg, H., Luceño, M., Märkl, W., Valcárcel, V., Bräuchler, C., Vargas, P. and Heubl, G. 2007. Molecular systematics and biogeography of Resedaceae based on ITS and trnL-F sequences. Mol. Phylogenet. Evol. 44: 1105-1120.

Miller, A.G. and Nyberg, J.A. 1994. Studies in the flora of Arabia: XXVII some new taxa from the Arabian Peninsula. Edinb. J. Bot. 51(1): 33-47.

Müller, A.J. 1864. Resedaceae. In: De Candolle, A.P. (Ed.) Prodromus Systematis Naturalis Regni Vegetabilis, Victor Masson, Paris 16(2): 548-589.

Swofford, D.L. 2002. PAUP* (v. 4.0b10). Phylogenetic analysis using parsimony (* and other methods). Sinauer Associates, Sunderland.

Taberlet, P., Gielly, L., Pautou, G. and Bouvet, J. 1991. Universal primers for amplification of three noncoding regions of chloroplast DNA. Plant Mol. Biol. 17: 1105-1109.

Thompson, J.D., Gibson, T.J., Plewniak, F., Jeanmougin, F. and Higgins, D.G. 1997. The Clustal_X windows interface: Flexible strategies for multiple sequence alignment aided by quality analysis tools. Nucleic Acids Res. 24: 4876-4882.

White, T.J., Bruns, T., Lee, S. and Taylor, J. 1990. Amplification and direct sequencing of fungal ribosomal RNA genes for phylogenetics. In: Innis, M.A., Gelfand, D.H., Sninksky, J.J. and White, T.J. (Eds) PCR protocols: a guide to method and amplifications. Academic Press, San Diego, California, pp. 315-322. 